\title{
From Within Fur and Feathers: Animals in Canadian Literature
}

\author{
Introduction: Animals in the Canadian Critical Tradition
}

Writing in the Literary History of Canada almost thirty-five years ago, Alec Lucas noted that "nature writing, particularly the animal story, had its hay-day in the late nineteenth and early twentieth centuries. It has long past. Perhaps the literary vein has been worked out" (1965:404). In retrospect, Lucas's epitaph for animal presences in Canadian literature may be premature; writing in the same volume, no less a luminary than Northrop Frye noted, with no predictions for the genre's demise, "the prevalence in Canada of animal stories, in which animals are closely assimilated to human behaviour and emotions" (343). Indeed, according to Gaile McGregor, any survey of the foundational works of Ernest Thompson Seton and Sir Charles G.D. Roberts and the many animal imaginings offered by recent and contemporary authors reveals that "Canadians are fascinated by animals" (1985:192). Poets as diverse as Layton, Atwood, Ondaatje, Page, Lane, Acorn, and Nowlan (among others) have written of animals; novelists such as Fred Bodsworth, Sheila Watson, Marian Engel, and Thomas King have all created animal characters of one form or another. The proliferation of an increasingly urbane literature in the Canadian imaginative landscape may bear out Lucas's prediction for the demise of the animal genre at some future date, but for now the important position of non-human actors in the recent history of the Canadian imagination remains intact, a fact that has been further emphasized by the recent critical and commercial success of Barbara Gowdy's elephant novel, The White Bone.

Nonetheless (and despite the ongoing success of the genre), critical reaction to animal presence in Canadian literature has been sparse at best. ${ }^{1}$ Much of the early writing on Seton and Roberts concentrated on biographical details (see Poirier 1927, Read 1963) or on literary techniques associated with writing from the point of view of an animal (see Magee 1964). James Polk's 1972 article "Lives of the Hunted" was among the first serious attempts (after Lucas's chapter in Klink's Literary History) to define 
the animal story as an important sub-genre within the field of Canadian literature. The article is firmly entrenched in the literary nationalism of the period; it attempts to subsume the animal genre entirely within the identity crisis of an emerging nation, and Polk analyses the sympathetic stance of Seton and Roberts toward the sometimes brutal fate of the "lives of the hunted" as a larger political allegory for Canada's "victim" status as an American satellite. The animals with which Canadians sympathize are, to a large extent, reflections of ourselves. The Americans, with their romantic quests for iconic animals such as Moby-Dick and Faulkner's bear, are the hunters; Canadians, as exemplified by such enduring victims as Seton's Lobo the wolf and Redruff the grouse, are the hunted. Polk concludes with the suggestion that

as Canada's perennial questioning of its own national identity is increasingly coupled with a suspicion that a fanged America lurks in the bushes, poised for the kill, it is not surprising that Canadian writers should retain their interest in persecution and survival. (1972a:58)

Margaret Atwood's landmark study Survival, published only six months after Polk's article, borrows the victimhood and survival motifs and applies them to a wide range of themes in Canadian literature (depictions of nature as a howling monster, exploration literature, representations of Native Canadians). Atwood acknowledges her debt to Polk, "who thought first about animal victims," at the beginning of the book (1972b:5). She also devotes a chapter exclusively to the animal story in Survival, an essay that repeats Polk's thesis of the American hunter and the Canadian victim using examples from contemporary authors (Graeme Gibson's Communion, most centrally). ${ }^{2}$ For Atwood, Canadian animal stories are unique for their realism and

because the stories are told from the point of view of the animal. That's the key: English animal stories are about the "social relations," American ones are about people killing animals; Canadian ones are about animals being killed, as felt emotionally from inside the fur and feathers. (1972b:74, original emphasis)

Yet Atwood reduces the flesh and blood realism of the animal stories to a more abstract expression of a national Canadian psyche. The suffering and dying animals of Canadian fiction and poetry are, for Atwood, direct reflections of the nation's deepest cultural anxieties:

It is much more likely that Canadians themselves feel threatened and nearly extinct as a nation, and suffer also from life-denying experience as individuals-the culture threatens the "animal" within them-and their identification with animals is the expression of a deep-seated cultural fear. The animals, as Seton says, are us. (1972b:79)

Subsequent criticism of the animal story in Canadian literature is, in many cases, a direct response to Atwood's and Polk's survival/victimhood thesis. Writing only two years after Polk and Atwood, Patricia Morley argues that the struggle for survival contains redemptive potential rather than inevitable defeat. For Morley, "Seton's animals 
are first and foremost heroes.... Because of the animals' heroic proportions, the mode is more tragic than pathetic, with something of the affirmation and catharsis of tragedy" (1974:29). Conversely, Gaile McGregor finds too much "sweetness and light" (1985:198) in Morley's analysis of Seton, and suggests that the presence of a victim role in Canada's national character need not be denied for it to have positive implications. McGregor sees virtue in defeat and argues that "the animal symbol both reflects and elucidates some of the striking idiosyncrasies of our communal self-image ... our fascination with what we might call a passive role model" (201).

A more recent critic, Misao Dean, rejects the earlier survival thesis in favour of a more ideological and deconstructivist critique of Roberts's writing. She begins with the premise that "the language of Roberts's stories cannot transparently reproduce material reality, for no realism is transparent" (1996:3) and goes on to argue that the animals in Roberts's stories are nothing more than cardboard cut-out figures masquerading as politically charged “( $\mathrm{m}$ )animals" whose habits and behaviour represent not observed biological facts, but rather "the masculinist discourse of the early twentieth century in which the 'primal' experiences of hunting, scouting and woodcraft serve as an antidote for the feminised life of the industrial city dweller" (3).

There is something missing in all of these critical reflections: each author, in his or her attempt to impose contemporary critical concerns on the animal stories, forgets that Seton and Roberts were influenced by the scientific and philosophical debates of their own period. Questions concerning the importance of instinct and reason in determining animal behaviour, the degree of kinship between animals and human beings, and the possible existence of a moral consciousness among non-human beings were all, as we shall see, at the forefront of early twentieth-century natural history and biology in Canada and the United States. Roberts and Seton both regarded the animal stories as implicated in these debates because they were a hybrid literary form that sat on the boundary between natural science and fiction. However much nationalistic and masculinist discourse might be inferred from their work, it is clear from their writings that Seton and Roberts were more concerned about writing accurate natural history-stories that reflect the habits and behaviours of real animals within a fictional framethan with creating political allegories (like those of Orwell) out of the basic material of animal lives.

Though Atwood and Polk do comment on the "reality" of the animals in the stories of Seton and Roberts as one of the unique aspects of their work, they do so only to the extent that their pain and suffering-as felt from within "real" fur and feathers-contributes to a myth of Canadian nationalism. Indeed, each of the critics discussed thus far exposes the literary animal as a human composite construction (of national myths, ideologies, and moral maxims) but refuses to acknowledge the material, biological, and ecological concerns that inform Seton's and Roberts's work. More precisely, the authors forget that the stories are about human relationships to animals; about how observed animal behaviour-their "biological" habits, social behaviour, and abilities to reason and act as moral agents-positions them in relation to "us" within a larger ecological and philosophical framework. It is upon this boundary between human and animal, instinct and reason, biological fact and creative myth, that the animal sto- 
ries of Seton and Roberts sit, along with much of the subsequent Canadian animal literature that has appeared in the last century. By tracing the scientific and philosophical debates that surrounded and shaped Seton's and Roberts's animal stories and their subsequent influence on the evolution of realistic fiction, we might better characterize the Canadian literary animal less as symbolic reflection of ourselves and more as a creative attempt to comprehend our relationship to the other beings with which we co-inhabit the living world. 3

\section{Between Science and Fiction: The Stories of Seton and Roberts}

Perhaps the most remarkable thing about animals in Canadian literature is that they are there at all. John Berger has spoken of the cultural and physical marginalization of animals in the modern era-their segregation into zoos (and I might add wilderness areas) and their cultural appropriation as commodified pets and humanized cartoon characters in the imaginations of Walt Disney and Beatrix Potter. Berger has suggested that "the ultimate consequence of their marginalisation" is that the "look between animal and man, which may have played a crucial role in the development of human society, and with which, in any case, all men had always lived until a century ago, has been extinguished" (1980:26).

Throughout human history, animal stories have provided an important way of understanding and codifying the "look between animal and man." Animal tricksters such as Coyote, Raven, and Wolverine have all played a messenger role, bringing "news" from the non-human world to human society. In several cultures, Coyote (as just one example) fulfills several important cosmic tasks: he creates the world, brings fire to the people, and teaches them the appropriate fishing rituals (Bright 1993). Coyote is not, however, simply a projection of particular human meanings. On a very basic level, stories about the coyote-as-scavenger/thief and those recounting the problematic hunting partnership between badger and coyote reflect basic social and ecological relationships amongst animals and between human and non-human worlds. Paul Shepard, a naturalist and environmental philosopher, has argued persuasively that the non-human characters of many traditional animal stories "are like the composite soul of a species," and that "the Navajos, for example, never overlooked a larger context for their coyote stories, a world in which people are surrounded by real coyotes that catch mice, scratch fleas, and defecate" (1996:95).

The attempt by Seton and Roberts to create animal characters that are at least partly accurate and real is precisely the creative objective that is so often overlooked in the early Canadian animal stories. In his prefatory remarks to the famous collection Wild Animals I Have Known, Seton suggests that, first and foremost, his stories are not about animals that are humanized beyond recognition (as in the folk and fairy tale tradition); rather, his animal characters are demonstrably real: "these stories are true. Although I have left the strict line of historical truth in many places, the animals in this book were all real characters" (1977:7). Lobo the wolf, Redruff the grouse, and Bingo the dog are all tied to specific places and events (some of them, as in the case of Lobo, well known to the reading public). In many ways, Roberts goes much further than 
Seton in his assertion of human-animal continuity. He, like Seton, emphasizes the importance of realism and natural history to the development of the animal story:

Our chief writers of animal stories at the present day may be regarded as explorers of this unknown world, absorbed in charting its topography. They work, indeed, upon a substantial foundation of known facts. They are minutely scrupulous as to their natural history, and assiduous contributors to that science. (1900:17)

But Roberts also suggests that human and non-human continuities go far beyond a shared physicality: animals may reason, they possess constructive imaginations, and, according to Roberts, they have a soul. The contemporary writers of animal stories must be

diligent in their search for motives beneath the action. Their care is to catch the varying, elusive personalities which dwell back of the luminous brain windows of the dog, the horse, the deer, or wrap themselves in reserve behind the inscrutable eyes of all the cats, or sit aloof in the gaze of the hawk and the eagle. The animal story at its highest point of development is a psychological romance constructed on a framework of natural science. (1900:17)

Animals stories are therefore, to Roberts, potent reminders of our biological and psychological continuity with animal species. In fact, Roberts positions his animal stories as the primary imaginative vehicle through which a reader may bridge the conceptual gap between civilization and the natural world:

The animals story, as we now have it, is a potent emancipator. It frees us for a little while from the world of shop-worn utilities, and from the mean tenement of self of which we do well grow weary. It helps us to return to nature, without requiring that we at the same time return to barbarism. It leads us back to the old kinship of the earth, without asking us to relinquish by way of toll any part of the wisdom of the ages, any fine essential of the "large result of time." (1900:19)

Certainly, as Misao Dean argues, the "nature" that Seton and Roberts want us to return to is, in many respects, a creature of culture. Both authors were undoubtedly part of the Romantic "back to nature" movement that swept through North America as a response to turn-of-the-century industrialism, prompting the creation of outdoor clubs, conservation groups, the Boy Scouts, and Seton's own Woodcraft Movement (see Altmeyer 1995). Roberts's fiction, in particular, suffers from an overwrought romantic sentimentality-his novel The Heart of the Ancient Wood features a young girl named Miranda who has a strange power to sympathetically protect and control the abundant wildlife surrounding her mother's backwoods cabin.

Nevertheless, the nature that Roberts portrays in his novel is not merely a sentimental or pastoral landscape. Miranda may be a vegetarian and resolute anti-hunter out of sympathy for her animal "friends," but she detests wolves with a "whole-souled hate" 
and refers to them as "vermin" (1974:215). Anti-predator attitudes were certainly not uncommon at the time, even amongst wildlife lovers, but Miranda's morally "pure" relationship to nature continues a complex evolution as the novel proceeds. At one point in the narrative, she asks Dave the hunter to kill a lynx that is about to attack a deer. When he also kills the lynx's kittens out of mercy, Miranda is devastated, prompting Dave to "sow a few seeds of doubt in Miranda's mind as to the correctness of her theories" by suggesting that "'t aint possible to be consistent right through in this life; but what ye'll find, life'll make a fool o' ye at one point or another" (242). The comment foreshadows the climax of the novel, where Miranda must kill her beloved friend Kroof (a bear) in order to save Dave (with whom she has fallen in love).

The idea of the moral trade-off (i.e., Miranda killing one loved one to save another) is common in Roberts's fiction, a world in which, to paraphrase Dave, ethical consistency throughout the span of one's life is simply not possible. In the story "Savoury Meats," a hunter named Silas kills a doe to help fortify his ailing father. The meat does heal the father "more than any medicine" (1900:152), but the narrative closes with the gruesome death of the doe's abandoned fawn, a reminder that even the most morally benign actions can have horrible consequences for the creatures of the woods. Moral ambiguities also exist between stories. In one tale, "The Moonlight Trails," a trapper finds the remains of a baby rabbit in a snare and swears off trapping; in another, "The Treason of Nature," Roberts celebrates the stalking of a moose and the "fierce elemental pride of the hunter triumphant" (196).

Seton is no less certain of the absolute moral basis for cross-species relationships than his counterpart Roberts. In one famous story, he celebrates the ability of Tito the coyote to escape the depredations of "Wolver Jake or his kind" and "prosper in a land of man-made plenty, in spite of the worst that man can do" (1977:350-52). Conversely, in another famous story, "Lobo, King of the Currumpaw," the author tells of his hunt for a great New Mexican cattle-killing wolf. Although Seton refuses to kill the wolf after he has trapped him, Lobo dies shortly after he is chained to a stake in the back pasture. The author makes no grand moral statement at the end of the story but simply buries Lobo next to the Alpha female whom he had strangled to death earlier in the story.

Is there a point to all of the moral inconsistency in Seton's and Roberts's fiction beyond that of mere confusion? One possible reason for the incongruity is that Roberts and Seton wanted to avoid a summary dismissal for holding an overly simplistic and deterministic view of animal behaviour. But more importantly, there is a sense that the living beings who participate in the natural world about which they write (including humans) experience a tension between biological instinct and moral reason. For some to live, others must die, and killing remains an inevitable part of the trade-offs associated with ecological existence. More precisely, the "imperfect" interactions of these animals emphasize their status as both imaginative and biological creatures. Seton's and Roberts's animals are at once transcendental "types" and fallen creatures of flesh and blood, creative tropes and "real" animals, creatures of elemental myth and of basic biology. At the root, this is the unique innovation of these early Canadian animal stories: a realist depiction of nature as a living terrain that contains many living, breathing, and interacting subjects, as opposed to a purely imaginative 
nature that emphasizes picturesque or sublime qualities, as with the eighteenth-century landscape tradition, or one that emphasizes the creative experience of the human observer, as is common with Romantic literature.

The nationalist literary critic might be tempted at this point to suggest that the continuing presence of living animals (as opposed to nature as mere backdrop) in turnof-the-century Canadian literature distinguishes "our" ecological aesthetic from the American romantic landscape tradition, as exemplified by Emerson's overly aesthetic "seeing eyeball," or the more recent work of nature writers such as Annie Dillard and Scott Russell Sanders. There are, however, several good reasons not to push the Canada versus United States analysis too far. Most importantly, to do so would run the risk of practising the kind of thematic criticism-a tendency to impose single patterns on entire national literatures without recognizing counter-movements within the country or cross-border influences-which I reprimanded earlier in the work of Polk and Atwood. ${ }^{4}$ Indeed, though there are discernible differences between artistic representations of nature and animals by authors in the United States and Canada, there are also many points of intersection. The American author Jack London was a contemporary of and influence on both Seton and Roberts (though he more readily celebrated the domestication of wild animals and the advance of civilization), and all three authors were wildly popular on both sides of the border (see Polk's Wilderness Writers). Animal characters are also central to the recent American poetry and fiction of authors such as Simon Ortiz and Ursula K. Le Guin. Furthermore, landscape aestheticism, a genre that tends to depict living creatures as a passive part of the scenery, is not uncommon in Canadian arts and letters. Susan Glickman's recent critical work has traced the importance of sublime and picturesque landscape conventions in early Canadian poetry, and more contemporary popular works, such as those by Sharon Butala and Don Gayton, are tied firmly to the picturesque landscape tradition. Even Roberts had an alter ego as a landscape poet in the British romantic tradition (the literary output for which he is most widely respected today).

Clearly then, the prominence of the "Canadian" animal story at the beginning of the twentieth century cannot be attributed to the pervasive influence of the "Canadian psyche" but to the unique creative output and astonishing success of two prolific authors who were subject to a variety of national and pan-national intellectual influences. Indeed, if Seton's and Roberts's animal stories belong to any particular intellectual tradition, it is closer to that of North American and European natural history than to Canadian literary nationalism. Seton in particular was famous and influential on both sides of the border as a practising naturalist-his four-volume field guide, The Lives of Game Animals (1900), was cited widely as an authoritative scientific text until mid-century. Roberts's career as a literary figure was more varied than Seton's, and as a consequence his career as a naturalist was more limited. But as we have seen, Roberts was no less attentive to the descriptive framework of natural history in his literary work than Seton. Moreover, Roberts maintained a close personal and professional association with Seton, frequently visiting and viewing the latter's natural history collection housed at Wyndygoul (see Adams 1986:96). 
Significantly, both men were active participants in the larger debate concerning the implications of Darwinian evolutionary theory that encompassed much of the Western intellectual world at the time. In Canada, this debate was marked by a pronounced conservative resistance to the new evolutionary model. Prominent naturalists of the generation preceding Seton's held tenaciously to the school of natural theology founded by Gilbert White a century earlier. Popular works of natural history such as Philip Henry Gosse's The Canadian Naturalist (1840) and Catherine Parr Traill's Studies of Plant Life in Canada (1906) celebrated the act of nature observation as one that brought the naturalist into close contact with God's creation. For almost two decades after the early 1870s, when the majority of academic natural scientists had accepted the basic framework of evolutionary theory, the McGill geologist William Dawson, his Toronto counterpart Daniel Wilson, and the French Canadian clergyman Abbé Léon Provencher all rejected major tenets of Darwinian evolution because the theory removed God's creative hand from the natural world. The anti-Darwinian sentiment of Canadian naturalists carried with it the idea that nature remained a moral terrain where the delight and appreciation of the naturalist awakened in him or her a heightened sense of virtue. They could not imagine a "nature" that was governed wholly by biological instinct because the idea negated the possibility that God was a moral presence in the natural world (see Carl Berger 1983:31-50; Zeller 1996:15-19).

There is little evidence to suggest that Seton and Roberts were direct adherents of natural theology, but their stories did popularize a scientific debate concerning the relative importance of animal instinct and intelligence that was raging not only among naturalists but among biologists in the emerging field of ethology (or animal behaviour). John Wadland has argued that the theories of behavioural scientists such as William Wheeler and C.O. Whitman concerning the importance of both instinct and learning to the development of all species, including humans, gave Seton the scientific authority he needed to produce fictional animals that were not merely mechanical beings but were capable of individualized behaviour (1976:191-214). Roberts also adopted one of the main premises of ethology (that instinct and reason act in tandem in all organisms) as a key focus for his animal fiction. He writes in his introduction to Kindred of the Wild that

whether it is avowedly or not, it is with the psychology of animal life that the representative animal stories of to-day are first of all concerned. Looking deep down into the eyes of certain of the four-footed kindred, we have been startled to see therein a something, before unrecognized, that answered to our inner and intellectual, if not spiritual selves. We have suddenly attained a new and clearer vision. We have come face to face with personality, where we were blindly wont to have predicated mere instinct and automatism. (1900:16)

Seton expounded on the same theme in his introduction to Wild Animals I Have Known, where he contends that the ability of animals to escape the bounds of instinct implies close affinity between themselves and humans:

such a collection of histories suggests a common thought-a moral it would have been called in the last century. No doubt each different mind will find a 
moral to his taste, but I hope some will herein find emphasized a moral as old as Scripture-we and the beasts are kin. Man has nothing that the animals have not some least a vestige of, the animals have nothing that man does not in some degree share. (1977:11-12)

Given the radical nature of their ideas and the unique nature of their fiction, it is perhaps unsurprising that Seton and Roberts touched off a major controversy between adherents of ethology and strict biological determinists when the famous American naturalist John Burroughs accused Seton of practising "sham" natural history in the March 1903 issue of The Atlantic Montbly (he was much more charitable to Roberts's work). Seton's crimes, according to Burroughs, were excessive anthropomorphism, the ascribing of improbable behaviours to animals, and a mixing of fact and fiction. President Theodore Roosevelt later weighed in on the debate and called Seton a "nature faker." (1907:17). The response of the two Canadians was muted-rumour has it that Seton confronted Burroughs at a party held by Andrew Carnegie three weeks after the publication of the Atlantic Montbly article, and Roberts defended his own work in the preface to The Watchers of the Trails with the suggestion that

a very distinguished author-to whom all contemporary writers on nature are indebted, and from whom it is only with the utmost diffidence that I venture to dissent at all-has greatly called me to account on the charge of ascribing to my animals human motives and the mental processes of man.... In my desire to avoid alike the melodramatic, the visionary, and the sentimental, I have studied well to keep within the safe limits of inference. (1904:ix)

Nonetheless, neither author was willing to renounce publicly or artistically the (ironically Darwinian) idea that humans and animals are kin or the decidedly non-Darwinian but logically consistent idea that all living creatures may reason and act as moral agents (see Adams 1986:92-105; Keller 1984:139-60).

It is precisely this intellectual and historical context which so many of the previously discussed literary critics have neglected in their assessments of Seton's and Roberts's work. By imposing the ideological and critical concerns of their own historical period-particularly cultural nationalism in the case of Atwood, Polk, and McGregor and deconstruction in the case of Dean-in their assessment of Seton's and Roberts's work, these critics have overlooked the fact that the animal stories address primarily the philosophical implications of late-nineteenth- and early-twentieth-century natural science rather than those of post-war literary criticism. Indeed, the suggestion of a biological affinity between animal and human by Seton and Roberts, combined with the constant presence of dying animals in the stories, was not intended to lament a "victimized" nation but rather to promote a sympathetic identification between the reader and the animal characters. Seton in particular combines the idea of human-animal kinship with the dying animal motif in an effort to instill in his readers a moral concern for wild animals. ${ }^{5}$ His Lives of the Hunted is dedicated "to the preservation of our wild creatures"; he writes in the introduction that 
my chief motive, my most earnest underlying wish, has been to stop the extermination of harmless wild animals.... I have tried to stop the stupid and brutal work of destruction by an appeal-not to reason: that has failed hitherto-but to sympathy, and especially to the sympathies of the coming generation. (1901:12-13)

In an even more famous passage, Seton mourns the slow death of Redruff the grouse (who is caught in a human-made trap) and asks, "Have the wild things no moral or legal rights? What right has man to inflict such long and fearful agony on a fellow-creature, simply because that creature does not speak his language?" (1977:297).

Seton's plea for a transformation in human values underscores a prominent theme in the animal stories: the idea that the observation and contemplation of animal behaviour may somehow lead to new human values. We have already seen that Roberts regarded his stories as a "bridge" between civilization and nature and that Seton saw his as a means to overcome the destructive behaviour of humans toward animals. The goal of both authors is to reconcile the basic facts of natural history with the larger moral questions that arise in their fictional narratives. Indeed, the intellectual history of the Canadian animal story is tied firmly to the turn-of-century effort to reconcile the older moralistic and theological approaches to natural history with the new biological approach of the twentieth century. Robert $\mathrm{H}$. McDonald, one of the few literary critics who has contextualized the work of Seton and Roberts as part of the debates surrounding late-nineteenth-century popular Darwinism, suggests that the animal stories are

part of a popular revolt against Darwinian determinism, and is an affirmation of man's need for moral and spiritual values... The works of Seton and Roberts are thus celebrations of rational, ethical animals, who, as they rise above instinct, reach toward the spiritual. This theme, inspired as it is by a vision of a better world, provides a mythic structure for what is at first sight, realistic fiction. (1980:18)

More recent Canadian animal literature has encompassed a wide variety of thematic concerns, but the pervasive influence of Seton and Roberts ties the genre firmly to a natural history tradition, one that attempts to reconcile instinct with reason, biology with myth, human with animal, and physical fact with fictional narrative.

\section{Beyond Seton and Roberts: Canadian Animal Literature of the Post-War Period}

The creative effort to straddle the line between fictional narrative and the "real lives" of animal creatures has survived, even flourished, in post-war Canadian literature. The production of animal fiction may be sporadic, but the experimental efforts of various authors to create fiction out of the basic material of animal lives has been no less successful in more recent times than at the start of the twentieth century (garnering huge sales, a Governor General's Award for Marian Engel's Bear, and a recent Governor General's Award nomination for Barbara Gowdy's The White Bone). 
Writing at mid-twentieth century, the naturalist, environmental activist and author Fred Bodsworth was the most obvious immediate heir to the Seton/Roberts tradition, as both animals and natural history figure prominently in his work. Bodsworth's novel The Strange One (1959), for example, traces the parallel journey of an ornithologist and barnacle goose to northern Canada; a second novel, The Atonement of Ashley Morden (1964), follows the life of a young bird enthusiast as he goes to war as a bomber pilot (a cruel parody of his former interest) and later finds refuge in the "pure wilderness" of Northern Ontario. Although human characters dominate both of these novels, Bodsworth's interest in natural history is at the forefront, as the main characters spend a great deal of time observing and contemplating the behaviour of animals. Bodsworth acknowledges his literary debts in the early chapters of Morden, in which his main character is introduced in childhood to natural history through the animal stories of Seton and Roberts.

Despite the reference to his predecessors in his later work, the direct influence of Seton and Roberts on Bodsworth's fiction is more readily apparent in his first novel, Last of the Curlews (1955). The narrative follows the perilous migration route of a single Eskimo curlew, and, like many of the earlier animal narratives, is told from the animal's point of view. In addition, Bodsworth pays slavish attention throughout the novel to the details of natural history. The curlew does not speak or maintain interior conversations but acts as one would expect a "real" curlew to act (searching for food, seeking a mate, etc.). Out of this basic living material, Bodsworth re-creates the larger myth of the dying animal that was so conspicuous in Seton's stories. The novel's narrative frame, which appears in italicized fragments at the beginning of each chapter, shows clearly that the book is a historical account of the Eskimo curlew's extinction at the hand of human beings. Bodsworth's novel is therefore not a mere natural history posing as fiction but a representation of a more profound, almost mythic, narrative that traces "the last of a dying race," of which "even the memory of them is gone and only the legends remain" (1955:1-2).

Certainly, the "dying race" image puts us firmly within Atwood's victimhood territory. It is not clear, however, that there is an explicit allegorical connection is not clear between Bodsworth's curlew and Atwood's victimized Canadians within the novel. In fact, Bodsworth's lines of opposition in the novel run between human and nonhuman rather than Canadian and American. Bodsworth's story, like so many of the earlier animal stories, is an expression of pity for the dying animals and the physical and imaginative marginalization (to use John Berger's terms) of the non-human in the modern period. Bodsworth's novel at least suggests that the material eradication of wild animals is part of a larger process of dis-enchanting the world.

There are other recent Canadian authors who, like Bodsworth, have led dual careers as naturalists and writers of fiction. R.D. Lawrence's novels Gbost Walker (1983) and The White Puma (1990) include vivid and detailed descriptions of the lifeways of western cougars, told at least partly from the point of view of the animals themselves, along with a requisite plea for their preservation. But perhaps the most important development in the Canadian animal "story" in the last three decades is the attempt by many authors (even poets) with no strong ties to natural history tradition to write 
about animals. A collection of Canadian animal poetry, The Broken Ark, was released in 1971, and despite a variety of stylistic approaches, many of the key themes of the early animal stories-particularly the emphasis on biological accuracy and the lament for the human capacity to destroy animal life-are well represented in the volume. Nonetheless, the emphasis on wildlife preservation and the consistent reflection on the role of instinct and reason that were so prominent in Seton's and Roberts's work are more muted in the more "literary" versions of the animal story. A much more important recurring theme in the poems found in The Broken Ark is a metaphorical linking of the death of the animal with the death of the human capacity for creative or imaginative thought. Animals are often portrayed as powerful, mythic creatures with immense creative powers who are reduced by humans to mere biological creatures (usually dead ones) near the end of the poem. Alden Nowlan's "The Bull Moose," for example, tells the story of a moose who has "the ritual mask of a blood god," and comes "down from the purple mist of trees in the mountain" to the domestic realm of a cattle field (1971:25). But the humans who come to look can only trivialize the image of the moose, who appears to them as "the kind of pet/ women put to bed with their sons." Later on in the poem, "the women asked/ if he could have escaped from a Fair" and "the young men snickered and tried to pour beer/ down his throat, while their girl friends took their pictures." The moose becomes an unrecognized and failed redeemer as a "giggling girl" places "a little purple cap/ of thistles [not thorns, in this case] on his head." When the moose tries to step outside the boundaries of human control and assert his wildness, he is no longer an acceptable curiosity for the domesticated imagination:

But just as the sun dropped in the river the bull moose gathered his strength like a scaffolded king, straightened and lifted his horns so that even the wardens backed away as they raised their rifles. When he roared, people ran to their cars. All the young men leaned on their automobile horns as he toppled.

(1971:25)

While the moose first appears as semi-divine teacher, he ends up a biologically dead being. Although Nowlan's poem certainly does grieve the physical death of the animals in much the same way as do Seton's stories, this lament is also for the death of the symbolic potency of the animal and, in a manner similar to Bodsworth's curlew novel, a testament to the ongoing disenchantment and destruction of the world.

The pattern repeats itself many times in the Canadian animal literature of the post-war period. Earl Birney's famous poem "Bear on the Delhi Road" tells the story of a tamed bear who must dance as entertainment for passing customers. Despite his degradation as a commodified object, the bear remains "tall as myth," and his trainers find it difficult to divorce the "real" biological bear from his symbolic associations:

it is not easy to

free myth from reality

or rear this fellow up 
to lurch lurch with them

in the tranced dancing of men

(1982:177)

Al Purdy's poem "The Beavers of Renfrew" places the archetypal "Canadian" animal at the centre of a creation myth, where the beavers, among other acts,

made a pact with men,

dammed the oceans for us,

chewed a hole in the big log bridge

wedged between Kamatchka and Alaska,

tore open the Mediterranean,

parted the Red Sea for Moses,

drowned Atlantis and the myth of original sin.

(1971:38)

Near the end of the poem, however, the beavers remain just beavers; the human mind is finally unable to divorce their symbolic potency from their status as material beings:

But the rest of it I have forgotten, and the gentle beaver will not remind us: standing upright at their earthen dams holding the moonlight reins of water, at peace with themselves

(1971:39)

There are many further examples in Canadian animal literature of creative power collapsing into a deadened biological reality: Layton's bull calf, whose pride reminds the author of a "deposed Richard II" (1982:239), ends up unceremoniously dead in a pit; Patrick Lane's wild horses who, "driving out of the high Rockies," become nothing more than "three hundred bucks of meat" (1982:212); and Acorn's elephants with their "five pound brains" and thoughts that range from those "long and solemn as novels" to "no thought[s]/ but twenty tons of lust as he fishes madly for whales/ and spiders to rape them" (1971:15). The juxtaposition of animal lives and (usually) human violence recalls Dennis Lee's image of a "savage field" in Canadian literary landscape, a strife-torn metaphysical terrain where the elements of earth (i.e., nature) are in perpetual conflict with the forces of world (civilization). Lee's "environmental" critical model suggests that the dying animal motif that was so prevalent in Canadian literature reflected a wider public concern that emerged in the early 1970s about the consequences of ecological destruction (species extinction, dying lakes, etc.). Literary animals who were shot, beaten, and unceremoniously killed may therefore have simply been creative "cannon fodder" in a larger effort to record destructive human behaviour toward the natural world.

Nonetheless, an over-emphasis on the "savage field" model as a unifying theme for all post-war animal literature risks committing the worst fallacy of "thematic" criticism: excluding all other literary traditions in an overzealous effort to make a body of work 
"fit" a particular pattern. Indeed, recent Canadian authors have not relied exclusively on violence and death (in the tradition of Seton's "shared fate" and "tragic end" theories) as a key theme for their animal creations. ${ }^{6}$ Thomas King's use of the Coyote trickster figure of Midwestern Native mythologies, for example, often results in a victory for the animal figure (and Native people) over the forces of colonialism. In his Green Grass, Running Water (1993), Coyote appears as a traditional "fixer" who makes the world right by destroying a huge, exploitative dam project on a Blackfoot reserve in southern Canada.

A further example that does not fit the dying animal pattern is Sheila Watson's seminal modern novel, The Double Hook (1966). The book is a spare, allusive narrative set in the caribou country of British Columbia, where the local Shuswap myth of the Trickster-Coyote is also employed, though not as a symbol of the passive dying animal but as a vital creative force within the novel. The action of the book takes place "under Coyote's eye"; as a character, he is not merely mythic backdrop for the novel but an active physical presence in the landscape: "That coyote plotting to catch all the glory for himself is fooled and every day fools others. He doesn't know, Kip thought, how much mischief Coyote can make" (1966:51). Coyote's almost god-like creative potential is confirmed at the end of the novel when a child is born and we hear

Coyote crying down through the boulders:

I have set his feet on soft ground;

I have set his feet on the sloping shoulders

of the world

(1966:118)

A further important example of creative potential and mythic vitality co-existing with the biological "reality" of an animal character is found in Marian Engel's novel Bear (1976). The plot revolves around a woman named Lou who has travelled to a remote island off the north shore of Lake Superior to conduct research in the library of an abandoned estate. Much to Lou's surprise, she finds a small, pathetic bear chained in the yard, an "unprepossessing creature" who was "not at all menacing" and "not at all a creature of the wild" (1976:36). But as the novel proceeds, the mythic stature, wildness, and creative potential of the bear become more apparent to Lou. Small notes fall out of library books as she conducts her research, many of them describing the symbolic significance of bears in various European countries. At the same time, the bear begins to sleep in the domestic and intellectual terrain of the library; the result is purely sensual and erotic as Lou begins a sexual relationship with the animal. As their encounters proceed, the bear takes on many of the qualities of a myth-animal. He is "wise and accepting" and "she [Lou] felt sometimes he was God" (118). The slips of paper that fall from the books begin to describe more comprehensive myths of crossspecies relationships, one slip saying only that "the offspring of a woman and a bear is a hero, with the strength of a bear and the cleverness of a man-Old Finnish legend" (99), an allusion to the widespread tradition of "Woman Who Married a Bear" stories in global mythology. 
The vital relationship between woman and bear does not last. Although the bear does not die, Lou does experience a demythification of the bear near the end of the novel, similar to that of Nowlan's moose. At one point in the narrative, Lou tells the bear to leave because "you have to go to your place and I to mine" (1976:131). Shortly after this rejection, the bear is finally aroused sexually (after several unsuccessful attempts), but Lou's invitation for the bear to enter her is met with a violent attack. The transcendent and redemptive quality of Lou's experience becomes fleeting and momentary. She wonders "what had passed from him to her.... Certainly it was not the seed of heroes, or magic, or any astounding virtue, for she continued to be herself' (136). Lou does feel "clean, simple and proud" (137) because of her sexual contact with the bear, but the result is more therapeutic than transformative, enabling Lou to resume her existence within the boundaries of civilized life. When she leaves the island, the bear is drained of its mythic, redemptive potency (unlike Watson's and King's Coyote); it appears to Lou only as "a fat, dignified old woman" (138) as it is driven in a motorboat to a new owner.

Although the animals of Watson's and Engel's fiction sit firmly on the boundary between physical reality and myth, they are less biological and slightly more enigmatic than those in the naturalist tradition of Seton, Roberts, and Bodsworth. A more dramatic assimilation of myth and biology in Canadian animal fiction comes from the recent example of Barbara Gowdy's The White Bone (1998). Gowdy's interest in elephants was sparked by a chance viewing of a National Geographic documentary on the work of prominent elephant behavioural scientist Cynthia Moss. She was particularly intrigued by Moss's descriptions of the almost religious practices of her elephant subjects, which included burying the bones of the dead and passing a hind leg over the burial site in a ritual fashion. Gowdy travelled to Kenya's Mara Reserve in 1996 to undertake her own intense observations of elephant behaviour. As a consequence, Gowdy's novel portrays the life of African elephants in a vivid, naturalistic detail-the animals' mating habits, feeding requirements, matriarchal social structure, birthing process, and movement patterns are described with a rigour that matches Seton's, Roberts's, and Bodsworth's attentiveness to natural science. ${ }^{7}$

Gowdy also became interested in theories of animal consciousness (see Bemrose 1998; Nickson 1988); she cites Moss's and Joyce Poole's radical behavioural studies on the complex social and communicative practices of elephants as major influences on The White Bone. ${ }^{8}$ Indeed, where Gowdy differs from many of the previously discussed authors is in her willingness to allow her elephants a full human-like consciousness as they speak and think openly throughout the novel. Gowdy's particular innovation for the animal story is to create characters that retain a certain biological verisimilitude but also have a complex culture and myth-structure of their own. The central plot is a search for the legendary white bone that will lead the elephants to the "safe place" far removed from the violent incursions of human hunters. Many of the elephants can "mind speak" and have visions. In one remarkable passage, the status of the elephants as both myth-bound and biological creature is accentuated when a male tells the tale of the white bone in the middle of his mating frenzy: 
"The end of the white bone points you-!" Each word an over-enunciated explosion. He paused. "That points you in the right direction," he continued calmly, "is, naturally, the pointed end... I myself was searching, or I was before this ... before this"-he flailed his trunk at his temporin, his flagellating penis_-"madness," he said miserably. (1998:72)

Of course, it can be argued here that Gowdy has completely anthropomorphized her elephant characters, but that is to miss the point. Gowdy is surely not asking her readers to accept her "cultural" elephants as entirely accurate representations, but rather to accept the idea that "real" biological animals may have cultural experiences similar in kind to those of human beings. Moreover, Gowdy's explicit political project (outlined in the afterword) to raise awareness about the depredations of the ivory trade takes the form, much like Seton's stories, of an imaginative plea for sympathy toward dying animals that arises from an awareness of their status as both biological and cultural creatures (rather than the abstract and objective population statistics that a scientist might use to argue the case). Thus, like many of the fictional animals outlined above, Gowdy's elephants straddle the line between biology and myth in a way that emphasizes their continuity with, and relationship (negative or positive) to, human beings. Gowdy's elephants live in a parallel rather than separate world from humans, a status that links "their" experience to "ours" across the widening gulf of the inter-species divide.

Gowdy's work represents only the latest offering in a century of Canadian creative writing about animals. The animal characters who inhabit such fiction do, as the work of Atwood, Polk, and Dean argues, carry the baggage of human social constructions, psychological projections, and political platforms. Nonetheless, Canadian literary animals are also, to a certain extent, contextual and real. They offer a deeper understanding of the relationship between human and animal rather than a mere abstract representation of non-human lives as symbolic representations of ourselves. As John Berger reminds us, "animals offer man a companionship which is different from any offered by human exchange. Different because it is offered to the loneliness of man as a species" (1980:4). To look at the "Other" and see only human selves provides narcissistic alienation from the world around us. For all its eclectic variations, one of the distinct achievements of Canadian animal literature has been to resist this alienation; to consider the composite myth-personalities of real biological animals rather than simply appropriate them for some "greater" cultural or political purpose.

\section{Notes}

I. The relative absence of critical discussion may reflect an academic fear within the humanities that animals are a subject worthy of consideration. For the "serious literary critic," there may also be a fear of working with a form associated with children's literature. 2. Atwood's criticism is, of course, doubly interesting because she applies her theoretical ideas directly to her fiction and poetry in so many cases. The main character (and narrator) in Surfacing, a novel published roughly at the same time as Survival, depicts a group of American fishermen and hunters as "happy killers" with "no conscience or piety; for them, the only things worthy of life were human, their own kind of human, framed in the proper clothes and gimmicks, laminated. It would have been different in those countries where an animal is the 
soul of an ancestor or the child of a god, at least they would have felt guilt" (1972a:128).

When she learns that the fishermen are not Americans, she concludes that

it doesn't matter what country they're from ... they're still Americans, they're what's in store for us, what we are turning into. They spread themselves like a virus, they get into the brain and take over the cells and the cells change from inside and the ones that have the disease can't tell the difference. (1972a:129)

3. I do not mean to reject completely the social constructivist view of earlier critics but merely to suggest that there remains some "flesh and blood" reality in the animals that inhabit Canadian literature.

4. There has been much debate on the merits of thematic criticism in the Canadian critical canon, and a full discussion is beypnd the scope of this paper. The term was coined by Frank Davey in an influential 1976 paper, "Surviving the Paraphrase," in which he attacked the overly general approach of Atwood and Frye. For a very complete discussion of thematic criticism, see Glickman (1998:54-58).

5. Seton's stance likely reflects his close association with the radical American preservationist and anti-sport hunting crusader William T. Hornaday (see Wadland 1976:231-46).

6. Though it is not widely practised today, there has also existed a tradition of hunting literature in Canada that celebrates the killing of animals as a noble pursuit. Though neither author was born in Canada, George Allen England's Vikings of the Ice (1924) depicts the Newfoundland sealers as noble figures who are victims of poverty, while Warburton Pike's The Barren-Grounds of Northern Canada (1892) recounts in almost reverent terms the author's journey to the Northwest Territories to hunt musk oxen. See Major W. Ross King (1866). For an overview of Victorian hunting literature, see Moyles and Owram (1988:6I-86).

7. If Gowdy's bibliography is any indication, she has read a wide body of natural science literature on elephants.

8. Gowdy cites Moss's Echo of the Elephants (1992) and Poole's Coming of Age With Elephants (1996), along with lain and Oria Douglas-Hamilton's earlier work, Among the Elephants (1975), as the major influences on the novel.

\section{References}

Acorn, Milton. 1971. The natural history of elephants. In The broken ark: A book of beasts, edited by Michael Ondaatje. Toronto: Oberon Press.

Adams, John Coldwell. 1986. Sir Charles God Damn: The life of Sir Charles G.D. Roberts. Toronto: University of Toronto Press.

Altmeyer, George. 1995. Three ideas of nature in Canada, 1893-1914. In Consuming Canada: Readings in environmental history, edited by Pam Gaffield and Chad Gaffield. Toronto: Copp, Clark. Atwood, Margaret. 1972a. Surfacing. Toronto: General Publishing.

1972b. Survival: A thematic guide to Canadian literature. Toronto: Anansi.

Bemrose, John. 1998. Elephantine fantasies: Triumphs with a pachyderm saga (The white bone). Maclean's, II September, 56-57.

Berger, Carl. 1983. Science, God and nature in Victorian Canada. Toronto: University of Toronto Press. Berger, John. About looking. New York. 1980.

Birney, Earl. 1982. The bear on the Delhi road. In Canadian poetry: Volume one, edited by Jack David and Robert Lecker. Toronto: ECW. 
Bishop, Elizabeth. 1979. The moose. In The complete poems, 1927-1929. New York: Farrar, Straus and Giroux.

Bodsworth, Fred. 1955. Last of the curlews. Washington: Counterpoint.

- 1959. The strange one. New York: Dodd, Mead and Co.

1964. The atonement of Ashley Morden. Toronto: McClelland \& Stewart.

Bright, William. 1993. A coyote reader. Berkeley: University of California Press.

Burroughs, John. 1903. Real and sham natural history. The Atlantic Monthly 91, March, 298-309.

Davey, Frank. [1976]. 1983. Surviving the paraphrase: Eleven essays on Canadian literature.

Winnipeg: Turnstone.

Dean, Misao. 1996. Political science: Realism in Roberts's animal stories. Studies in Canadian Literature 21, no. 1: 1-16.

Engel, Marian. 1976. Bear. Toronto: McClelland \& Stewart.

England, George Allen. 1924. Vikings of the ice, being the log of a tenderfoot on the great Newfoundland seal hunt. Garden City, NJ: Doubleday, Page \& Company.

Frye, Northrop. 1976. Conclusion to Literary history of Canada: Canadian literature in English. $2 d$ ed. Vol. 2. Edited by Carl F. Klinck. Toronto: University of Toronto Press.

Gibson, Graeme. 1971. Communion. Toronto: Anansi.

Glickman, Susan. 1998. The picturesque and the sublime: A poetics of the Canadian landscape. Montreal: McGill-Queen's University Press.

Gosse, P.H. 1840. The Canadian naturalist: A series of conversations on the natural history of Lower Canada. London: John Van Voorst.

Gowdy, Barbara. 1998. The white bone. Toronto: HarperCollins.

Keller, Betty. 1984. Black wolf: The life of Ernest Thompson Seton. Toronto: Douglas \& Macintyre.

King, Thomas. 1993. Green grass, running water. Toronto: HarperCollins.

King, Major W. Ross. 1866. The sportsman and naturalist in Canada. London: Hurst and Blackett. Lane, Patrick. 1982. Wild horses. In Canadian poetry: Volume two, edited by Jack David and Robert Lecker. Toronto: ECW.

Lawrence, R.D. 1983. The ghost walker. New York: Holt, Rhinehart and Winston. 1990. The white puma. Toronto: Stoddart.

Layton, Irving. 1982. The bull calf. In Canadian poetry: Volume one, edited by Jack David and Robert Lecker. Toronto: ECW.

Lee, Dennis. 1977. Savage fields: An essay in literature and cosmology. Toronto: Anansi.

Lucas, Alec. 1965. Nature writers and the animal story. In A literary history of Canada. Vol. I. Edited by Carl F. Klinck. Toronto: University of Toronto Press.

Magee, William H. 1964. The animal story: A challenge in technique. Dalhousie Review 44, Summer: 156-64.

McDonald, Robert. 1980. The revolt against instinct: The animal stories of Seton and Roberts. Canadian Literature 84: 18-29. 
McGregor, Gaile. 1985. The Wacousta syndrome: Explorations in the Canadian landscape. Toronto: University of Toronto Press.

Morley, Patricia. 1974. Survival, affirmation and joy. Lakehead University Review 7, no I: 21-30.

Mowat, Farley. 1990. Rescue the Earth! Conversations with green crusaders. Toronto: McClelland \& Stewart.

Moyles, R.G., and Doug Owram. 1988. Imperial dreams and colonial realities: British views of Canada 1880-1914. Toronto: University of Toronto Press.

Nickson, Elizabeth. 1988. In the skin of an elephant: Literary daredevil. Saturday Night II3, no. 7, 56-63.

Nowlan, Alden. 197I. The bull moose. In The broken ark: A book of beasts, edited by Michael Ondaatje. Ottawa: Oberon Press.

Pike, Warburton. 1892. The barren ground of northern Canada. New York: Macmillan.

Poirier, Michel. 1927. The animal story in Canadian literature. Queen's Quarterly 34: 298-312, $398-419$.

Polk, James. 1972a. Lives of the hunted. Canadian Literature 53: 51-59.

1972b. Wilderness writers. Toronto: Clark \& Irwin.

Purdy, Al. 197I. The beavers of Renfrew. In The broken ark: A book of beasts, edited by Michael Ondaatje. Ottawa: Oberon Press.

Read, S.E. 1963. Flight to the primitive. Canadian Literature 13: 45-57.

Roberts, Sir Charles G.D. 1900. Kindred of the wild: A book of animal life. New York: Thomas Nelson and Sons.

1904. The watchers of the trails: A book of animal life. Toronto: Copp, Clark.

1974. The heart of the ancient wood. Toronto: McClelland \& Stewart.

Roosevelt, Theodore. 1907. Nature fakers. Everybody's magazine, September, 17.

Seton, Ernest Thompson. 190I. Lives of the hunted. Toronto: George N. Morang and Co.

1929. Lives of game animals: An account of those land animals in America, north of the Mexican border, which are considered game, either because they have held the attention of sportsmen, or received the protection of law. Vols. 1-4. Garden City, NJ: Doran.

. 1977. Wild animals I have known. Toronto: McClelland Stewart.

Shepard, Paul. 1996. The others: How animals made us human. Washington, DC: Island Press.

Traill, Catherine Parr. 1906. Studies of plant life in Canada. Toronto: William Briggs.

Wadland, John. 1976. Ernest Thompson Seton: Man and nature in the progressive era, 18801915. Ph.D. diss. York University, Toronto.

Watson, Sheila. 1966. The double hook. Toronto: McClelland \& Stewart.

Zeller, Suzanne. 1996. Land of promise; Promised land. Ottawa: Canadian Historical Association. 